University of Nebraska - Lincoln

DigitalCommons@University of Nebraska - Lincoln

USDA National Wildlife Research Center - Staff Publications
U.S. Department of Agriculture: Animal and Plant Health Inspection Service

2011

\title{
Use of glyphosate for managing invasive cattail (Typha spp.) to disperse blackbird (Icteridae) roosts
}

George M. Linz

USDA/APHIS/WS National Wildlife Research Center, george.m.linz@aphis.usda.gov

H. Jeffrey Homan

USDA/APHIS/Wildlife Services' National Wildlife Research Center, jeffrey.h.homan@aphis.usda.gov

Follow this and additional works at: https://digitalcommons.unl.edu/icwdm_usdanwrc

Linz, George M. and Homan, H. Jeffrey, "Use of glyphosate for managing invasive cattail (Typha spp.) to disperse blackbird (Icteridae) roosts" (2011). USDA National Wildlife Research Center - Staff Publications. 1328.

https://digitalcommons.unl.edu/icwdm_usdanwrc/1328

This Article is brought to you for free and open access by the U.S. Department of Agriculture: Animal and Plant Health Inspection Service at DigitalCommons@University of Nebraska - Lincoln. It has been accepted for inclusion in USDA National Wildlife Research Center - Staff Publications by an authorized administrator of DigitalCommons@University of Nebraska - Lincoln. 
Review

\title{
Use of glyphosate for managing invasive cattail (Typha spp.) to disperse blackbird (Icteridae) roosts
}

\author{
George M. Linz*, H. Jeffrey Homan \\ U.S. Department of Agriculture, Wildlife Services, National Wildlife Research Center, 2110 Miriam Circle, Suite B, Bismarck, ND 58501, USA
}

\section{A R T I C L E I N F O}

\section{Article history:}

Received 14 June 2010

Received in revised form

28 September 2010

Accepted 8 October 2010

\section{Keywords:}

Blackbirds

Cattails

Glyphosate

Sunflower damage

Typha spp.

Wetland management

\begin{abstract}
A B S T R A C T
Hybrid cattail (Typha $\times$ glauca Godr.) has become the dominant emergent vegetation in many wetlands of central North America's Prairie Pothole Region (PPR). Hybrid cattail, an invasive species, can outcompete native emergents and form a dense canopy that alters the original physiognomy and ecological processes of the wetland. Blackbirds (Icteridae), which number in the millions in late summer in the PPR, use cattails for reproduction, loafing and roosting. Ripening crops, especially sunflower, planted near wetland roost sites can sustain considerable economic damage from blackbirds. Producers of sunflower in North Dakota and South Dakota can obtain assistance from the U.S. Department of Agriculture's Wildlife Services unit to prevent blackbird damage. Beginning in 1991, Wildlife Services began aerially spraying cattails with glyphosate herbicide to reduce roosting substrate and lessen the severity of localized sunflower damage. As the program enters its 20th year, we review published research aimed at assessing the ecological effects and efficacy of glyphosate use in wetlands. Additionally, we incorporate unpublished data gathered to enhance the program's environmental safety and efficacy.
\end{abstract}

Published by Elsevier Ltd

\section{Introduction}

\subsection{Sunflower and blackbirds}

Sunflower is an important commodity to rural economies of North Dakota and South Dakota (Bangsund and Leistritz, 1995). In 2009 , these 2 states produced $76 \%\left(1.1 \times 10^{6}\right.$ metric tons $)$ of the U.S. crop (NASS, 2010a). Sunflower became a viable rotational crop in the region in the early 1970s; and from the start, blackbirds (Icteridae) targeted it as a major source of food (Guarino and Cummings, 1985; Hothem et al., 1988; Linz et al., 2002). Blackbirds gorge on the calorie-rich sunflower achenes throughout late summer and early fall preparing for the physical and energetic stresses of migration (Linz et al., 1983b, 1984; Homan et al., 1994). The 3 species causing damage, in order of importance, are the redwinged blackbird (Agelaius phoeniceus L.), common grackle (Quiscalus quiscula L.) and yellow-headed blackbird (Xanthocephalus xanthocephalus Bonaparte). In aggregate, about 75 million blackbirds stage in North Dakota and South Dakota over the duration of pre-migratory and migratory periods beginning in late August and ending in October (Peer et al., 2003).

\footnotetext{
* Corresponding author. Tel.: +1 701250 4469; fax: +1 7012504408 .

E-mail address: george.m.linz@aphis.usda.gov (G.M. Linz).
}

Annually, U.S. Department of Agriculture's Wildlife Services (USDA-WS) receives hundreds of requests for assistance to protect agricultural crops from damage caused by blackbirds. A majority of requests are for protection of sunflower fields planted near cattaildominated wetlands, where damage can be economically unsustainable, forcing some growers to remove sunflower from planting rotations (Linz and Homan, 1998; Kleingartner, 2002). In fact, Otis and Kilburn (1988) found that the main predictor of severity levels of blackbird damage is presence-absence of nearby wetlands, with fields located near wetlands receiving $2-4 \times$ more damage. A cattail-dominated wetland can harbor $>70,000$ blackbirds, with wetlands containing $>20,000$ birds being common in North Dakota (Linz et al., 2003). Blackbirds emanating from cattail roosts employ a foraging strategy that limits their activity radii. For example, $>80 \%$ of sunflower fields visited by radio-tagged redwinged blackbirds occurred $\leq 10 \mathrm{~km}$ from roost sites (Besser et al., 1981). Choosing the closest available high quality food source provides the bird with an optimal energy gain per unit of energy expended and allows for more rapid storage of migratory energy reserves (Pyke, 1984). Additionally, blackbirds are molting in late summer, which hampers flight efficiency and tends to restrict flight distances (Linz et al., 1983a).

Peer et al. (2003) used bioenergetics and population models to determine that annual direct economic cost from blackbird predation was US\$5.0 to $\$ 10.0$ million. This estimate was 
comparable to the US\$4.0 to \$11.0 million loss calculated from field surveys of damage conducted statewide in North Dakota, South Dakota and Minnesota in 1979 and 1980 (Hothem et al., 1988). During these years, average field loss was $1-2 \%$, with $2 \%$ of surveyed fields showing losses $>10 \%$. This amount of damage should not cause serious conflicts between blackbirds and sunflower producers; however, the extent and pattern of damage are inadequately portrayed for the growers that plant in areas with high wetland densities. In the 1990s, 345 randomly selected fields in 4 important sunflower producing counties located in the Prairie Pothole Region (PPR) of North Dakota and South Dakota were surveyed for bird damage; of these, 36 (10\%) had damage $\geq 5 \%$ and $22(6 \%) \geq 10 \%$ damage (Linz et al., 2002). Damage $>5 \%$ is considered an economically important threshold. The high incidence of damage found in this survey probably resulted from a direct relationship between blackbird abundance and distribution of cattaildominated wetlands (Otis and Kilburn, 1988; Forcey et al. 2008).

In 1991, USDA-WS initiated a cattail management program in North Dakota and South Dakota with a goal to disrupt the critical habitat link between blackbird damage to sunflower and nearby cattail-dominated wetlands (USDA, 2006). Through 2009, USDAWS has annually sprayed about 1500 ha of cattail, using aerial applications of the herbicide, glyphosate. The techniques used by USDA-WS were developed by scientists over 20 years of experimental research that included studies on spray pattern (strips), percent coverage, glyphosate concentrations and volumes and environmental impacts. In this paper, we review the literature used to support scientific needs of the management program. Moreover, we incorporate findings from unpublished research that enhanced environmental safety and efficacy of the program as it developed and progressed.

\section{Cattails in the Prairie Pothole Region}

Narrow-leaved cattail (Typha angustifolia L.), an Old World species, was well established in eastern North America by the late 1800s (Hotchkiss and Dozier, 1949; Stuckey and Salamon, 1987; Kantrud, 1992). Narrow-leaved cattail hybridized with the indigenous common cattail (Typha latifolia L.) and produced a viable cross that is now considered a separate North American species, hybrid cattail (T. $\times$ glauca Godr.). Wind-borne seeds quickly established new stands. By the 1950s, both narrow-leaved and hybrid cattail were commonly found in the PPR (Stevens, 1963; Kantrud, 1992). Hybrid cattail is a generalist and can be found in shallow-water areas $(<30 \mathrm{~cm})$ and mudflats of wetlands, margins of ponds and lakes, roadside ditches, irrigation canals and backwater areas of rivers and streams. Once established at a site, it spreads rapidly through robust rhizomatous growth (Merendino and Smith, 1991; van der Valk and Davis, 1978).

Hybrid cattail is a successful invader and competitor with native emergents because it is tolerant of shade, moderate salinities, high concentrations of ammonium and water depths up to $72 \mathrm{~cm}$ (Waters and Shay, 1992). These characteristics give hybrid cattail a competitive edge that can result in exclusion of native emergent species (Weller, 1975; Davis and van der Valk, 1978; Farrer and Goldberg, 2009). By the 1970s, hybrid cattail was the most abundant large hydrophyte in wetlands of the PPR (Kantrud, 1992; Galatowitsch and van der Valk, 1994). Wetlands, formerly consisting of mosaics of open water and sparse stands of hardstem bulrush (Schoenoplectus acutus, syn Scirpus; Buhl ex Bigelow A. Löve and D. Löve), were closed by dense canopies of hybrid cattail (Kantrud, 1992).

The loss of spatial heterogeneity caused by invasive cattail has resulted in declines in diversity and abundance of numerous wetland species and has provided a refuge for migrating blackbirds
(Kantrud, 1986; Solberg and Higgins, 1993; Linz et al., 2003). These concerns led Ralston et al. (2007) to estimate the areal coverage of cattail in North Dakota's PPR $\left(97,042 \mathrm{~km}^{2}\right)$ using $1203.2 \times 3.2 \mathrm{~km}$ sample plots. They identified 15,986 wetlands ( $=1.1 \mathrm{ha}$ ), with 4494 $(28 \%)$ wetlands $(=2.4$ ha) containing cattails. Coverage of cattail averaged $37 \%$ of wetland basin areas. Semipermanent wetlands contained over $50 \%$ of the total cattail observed in the sample. Semipermanent wetlands harbor the largest numbers of migrating blackbirds (Linz et al., 2003). In Stutsman County, North Dakota, which is a high sunflower production area, an average of 20,500 blackbirds used wetlands averaging 94 ha (Linz et al., 2003).

\section{Glyphosate herbicide}

\subsection{Glyphosate properties}

Mechanical methods for managing cattail (e.g., burning, mowing and disking) are labor-intensive, expensive and often ineffective because the stands quickly reestablish themselves through vigorous growth of rhizomes (Beule, 1979). Moreover, semipermanent wetlands typically contain sufficient standing water to prevent use of mechanical equipment. It is possible to manage cattails by flooding, but wetlands in the PPR seldom have water controls to facilitate this action. To overcome these impediments, state and federal government agencies have opted to use aerially applied glyphosate herbicide for controlling cattails (Sojda and Solberg, 1993; Solberg and Higgins, 1993; Linz et al., 2004). Aerial application is the best method for managing cattail in semipermanent wetlands because basin areas are usually too large for ground-based sprayers (Linz et al., 2003).

Glyphosate ([N-(phosphonomethyl) glycine], Chemical Abstract Number 1071-83-6), is a systemic, broad-spectrum, post-emergence herbicide registered by the U.S. Environmental Protection Agency (USEPA) in 1974 and reregistered in 1993 (USEPA Reg. No. 524-343). The Monsanto Company (St. Louis, Missouri, USA) held the patent on the glyphosate molecule until the year 2000; thereafter, a number of companies began formulating and selling glyphosate under a myriad of trade names. In this paper, we refer only to the aquatic formulations of glyphosate and provide mass in acid equivalents. We caution that glyphosate formulated for terrestrial uses may contain non-herbicidal components and surfactants [e.g., POEA (polyoxyethylene-alkylamine)] that have been found harmful to aquatic life in vitro (Folmar et al., 1979; Henry et al., 1994; Mann and Bidwell, 1999; Howe et al., 2004; Relyea, 2005).

Glyphosate is most effective in late summer when cattails are actively metabolizing and transporting carbohydrates to their rhizomes. Glyphosate inhibits protein synthesis by blocking the shikimic acid pathway, a metabolic pathway not present in vertebrates and invertebrates (Cole, 1985; Franz et al., 1997; Alibhai and Stallings, 2001). Plants treated with glyphosate show stunted growth, yellowing, leaf wrinkling and wilting, with tissue death occurring 4-20 days following application (Franz et al., 1997). When treating emergents, the potential exists for glyphosate to reach surface waters. On contact with surface water, glyphosate's herbicidal activity decreases rapidly by 1 ) adsorption to suspended soil particles and sediment, 2) microbial degradation and 3) photolysis (Bronstad and Friestad, 1985). The major pathway for the compound's destruction is microbial degradation. The half-life of glyphosate in soils and water is 3-140 and 12-70 days, respectively. Linz et al. (1999) monitored glyphosate-treated and reference wetlands for 2 years and found no significant post-treatment effects for abiotic variables, including water temperature, $\mathrm{pH}, \mathrm{PO}_{4}$, $\mathrm{NO}_{3}-\mathrm{N}$, dissolved $\mathrm{O}_{2}$ and total conductivity. 


\subsection{Glyphosate efficacy on cattails}

In the 1970s, Mueller and Lembi (1975) and Lembi (1978) conducted efficacy trials with glyphosate on emergent vegetation, including cattails. Mueller and Lembi (1975) showed that glyphosate applied at $3.3 \mathrm{~kg} \mathrm{ha}^{-1}$ killed $40 \%$ of cattails during flowering, whereas $6.6 \mathrm{~kg} \mathrm{ha}^{-1}$ killed $60 \%$. In a later trial, Lembi (1978) found that $1.5 \mathrm{~kg} \mathrm{ha}^{-1}$ glyphosate killed $100 \%$. Lembi (1978) did not report the relationship of efficacy to timing of application or the longevity of control. Both pilot studies provided valuable data for future experimental research that led to registration of glyphosate for use on emergent wetland vegetation.

In 1983-1984, Comes and Kelley (1989) used an all-terrain vehicle to apply $2.2,3.4$ and $4.4 \mathrm{~kg} \mathrm{ha}^{-1}$ of glyphosate to cattail across 3 dates (early July, mid-August, mid-September) that corresponded developmentally to full bloom, post anthesis and seed maturity, respectively. The solutions contained $0.5 \% \mathrm{v} / \mathrm{v}$ surfactant and $2801 \mathrm{ha}^{-1}$ of water. They reported unsatisfactory results for the $2.2 \mathrm{~kg} \mathrm{ha}^{-1}$ treatment applied across all dates. However, efficacy of $3.4 \mathrm{~kg} \mathrm{ha}^{-1}$ and $4.4 \mathrm{~kg} \mathrm{ha}^{-1}$ was comparable across the August and September application dates. Increasing the water volume to 560 or $1120 \mathrm{l} \mathrm{ha}^{-1}$ did not improve efficacy (Comes and Kelley, 1989).

In August 1985 and July 1986, Solberg and Higgins (1993) used a fixed-winged aircraft to spray cattail-dominated wetlands in South Dakota with $7.01 \mathrm{ha}^{-1}\left(3.4 \mathrm{~kg} \mathrm{ha}^{-1}\right)$ glyphosate. [Note: we have determined and verified (Ken Higgins, Personnel communication) that the $2.81 \mathrm{ha}^{-1}$ rate published in Solberg and Higgins (1993) was a metric conversion error]. The $3.4 \mathrm{~kg} \mathrm{ha}^{-1}$ rate was the maximum rate permitted by the label at the time of the experiment (Monsanto Company, 1988). One year later, the authors reported that nearly $100 \%$ of the cattails were dead. Repeated annual visits to the sprayed wetlands showed that treatment effects lasted at least 4 years, if water depths were stable and reseeding thereby thwarted.

In 1987, Messersmith et al. (1992) used a backpack sprayer to apply glyphosate at 2 locations near Fargo, North Dakota, USA, across 3 dates (18 June, 27 July, 3 September), with 2 spray volumes $\left(75 \mathrm{l} \mathrm{ha}^{-1}, 224 \mathrm{l} \mathrm{ha}^{-1}\right.$ ) and 3 application rates $\left(1.7,2.6,3.4 \mathrm{~kg} \mathrm{ha}^{-1}\right)$. The authors found that cattail control was substantially reduced with the $1.7 \mathrm{~kg} \mathrm{ha}^{-1}$ application rate, whereas cattail control was nearly equal between the 2.6 and $3.4 \mathrm{~kg} \mathrm{ha}^{-1}$ rates. They found that control tended to be better for the later sprays than the mid-June spray. Spray volume had no effect on level of cattail control. Scientists for the USDA conducted several efficacy field trials between 1989 and 1998 (Homan et al., 1992; Linz et al., 1992, 1995, 1996a). All were conducted in North Dakota using fixed-wing aircraft. Except when testing efficacy related to application volumes, a spray volume of $47 \mathrm{l} \mathrm{ha}^{-1}$ was used. All trials focused on maximizing cost-benefits achievable through aerial applications, including use of below-label rates, low-volume solutions and synergistic effects of seasonal timing.

In August and September 1989 and 1990, Linz et al. (1992) conducted efficacy tests using 5 rates of glyphosate, ranging from 2.2 to $3.4 \mathrm{~kg} \mathrm{ha}^{-1}$. Cattail stems were counted just prior to spraying and during July and August in the following 2 years. The belowlabel rate of $2.2 \mathrm{~kg} \mathrm{ha}^{-1}$ controlled cattail as effectively as the minimum-labeled rate $\left(2.5 \mathrm{~kg} \mathrm{ha}^{-1}\right)$.

In mid to late July 1990 and 1991, Linz et al. (1996a) treated wetlands with $2.5 \mathrm{~kg} \mathrm{ha}^{-1}$ glyphosate applied in 15 -m wide parallel strips. Wetlands received $90 \%, 70 \%$ or $50 \%$ spray coverage, with the results compared to a set of reference wetlands. Analysis of falsecolor infrared, aerial images taken in August of the pre-treatment year showed that cattail coverage averaged $84 \%$ across all wetlands. After 2 years post-treatment, cattail coverage declined to $31 \%$ of the treated wetland basin areas, whereas cattails covered $65 \%$ of the reference wetlands. The areal coverages of living cattail were similar in post-treatment years across the 3 different spray coverages.

In 1992, wetlands were treated with $2.5 \mathrm{~kg} \mathrm{ha}^{-1}$ glyphosate and compared with reference wetlands. Analyses of aerial images showed that cattail coverage in treated wetlands was reduced from $70 \%$ to $26 \%$, with cattail coverage remaining the same for 2 years post-treatment (Homan et al., 1992; Linz et al., 1995). In reference wetlands, cattail coverage 1 year post-treatment remained near the $80 \%$ pre-treatment coverage; however, coverage declined to $40 \%$ in the second year post-treatment because of inundation of wetlands from above-normal levels of precipitation in 1993 and 1994. Other indicators of efficacy, such as declines in roost sizes and positive differences in sunflower production near treated wetlands compared to reference wetlands, were not statistically significant, perhaps caused by basin flooding and the concomitant loss of cattail coverage in all wetlands used in the sample (Linz et al., 1995). A linear regression analysis, however, yielded a strong positive relationship between sunflower production loss and blackbird roost size. Thus, providing evidence that fragmenting dense roosting habitat could reduce production losses resulting from foraging blackbirds.

Finally in mid- and late July and late August 1998, 5 cattaildominated wetlands ( $>70 \%$ coverage) in central North Dakota were treated with glyphosate at $47 \mathrm{lha}^{-1}$ and $281 \mathrm{ha}^{-1}$ (Homan, Unpublished data). The minimum label-recommended rate of glyphosate (2.5 $\mathrm{kg} \mathrm{ha}^{-1}$ ) was used (Monsanto Company, 1988). Application timing was also incorporated into the experiment by using early and late spraying periods. The volume treatments were applied alternately in strips $15 \mathrm{~m}$ wide, with each treatment lane separated by an untreated buffer strip of living cattail $6 \mathrm{~m}$ wide. One-half of the wetland was sprayed during mid- and late July (early) and the remaining half sprayed in late August (late). Analysis of infrared images showed similar percentages of living cattail across the 4 post-treatment years and among the 4 treatments (Fig. 1). By the fourth year post-treatment, however, all treatments started to show cattail regrowth, with the late period-low-volume treatment recovering at a faster rate than the other treatments. Even so, treated lanes only averaged 10\% living cattail over all

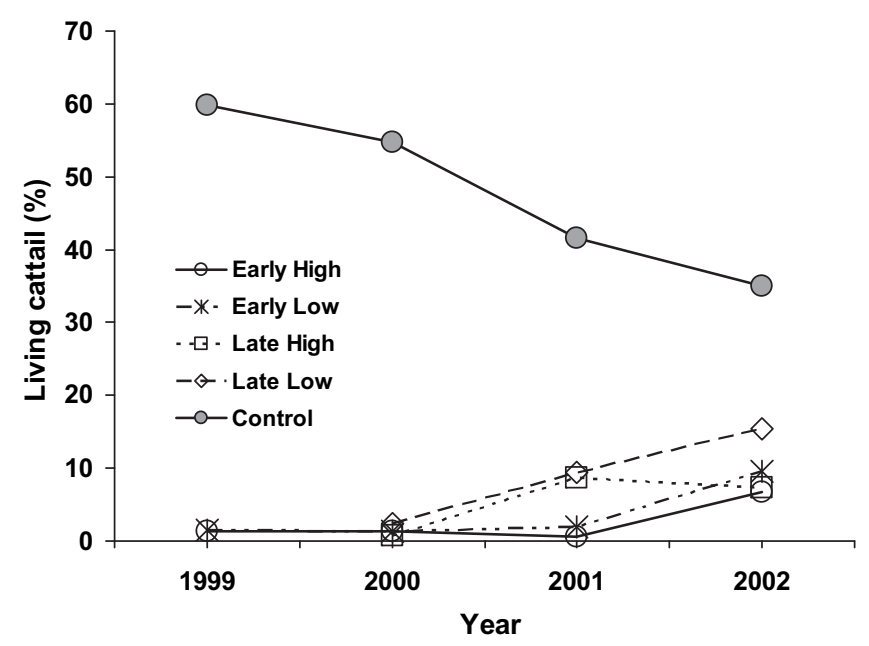

Fig. 1. The percentage of living cattail in five wetlands in North Dakota treated with glyphosate herbicide in 1998 and monitored for regrowth of cattail until 2002. There were 4 treatments including the combinations of early- (July) and late-date (August) sprays with high volume (47 l ha $\left.\mathrm{h}^{-1}\right)$ and low-volume $\left(28 \mathrm{l} \mathrm{ha}^{-1}\right)$. The relative standard error $(\mathrm{SE} / \bar{x} \times 100)$ averaged $48 \%$ over treatment years. 
treatment types compared to $>70 \%$ cattail coverage in all 5 wetlands during the pre-treatment period. Cattails sprayed in July collapsed prior to the onset of blackbird migration in late August, showing that early application of glyphosate could effectively eliminate roosting substrate within season. Cattails sprayed in late August, however, retained the necessary rigidity and stem density to accommodate roosting blackbirds until the following year.

\subsection{Glyphosate effects on aquatic organisms}

In the 1980s and 1990s, scientists investigated effects of aquatic formulations of glyphosate on invertebrate populations in laboratory and field settings. Solberg and Higgins (1993) found more aquatic invertebrates in untreated cattails of glyphosate-treated wetlands than in cattails from reference wetlands and found comparatively fewer invertebrates in glyphosate-treated portions of treated basins than in adjacent areas having untreated cattails. They speculated that some of the invertebrates moved from the treated areas to adjacent untreated areas of individual wetlands. These findings led to additional studies on the effects of glyphosate on aquatic invertebrates (Buhl and Faerber, 1989; Henry et al., 1994; Linz et al., 1999).

Buhl and Faerber (1989) conducted laboratory studies on midge larvae (Chironomus riparius Meigen) to assess acute toxicities of Rodeo $^{\circledR}$ (Monsanto Company, St. Louis, Missouri, USA) and 2 commonly used adjuvants [Activator N.F. ${ }^{\circledR}$ (Loveland Industries, Inc., Greeley, Colorado) and Ortho X-77 ${ }^{\circledR}$ (Chevron Environmental Health, Richmond, California)]. The authors found that the 48-h $\mathrm{EC}_{50}$ value (median effective concentration) for Rodeo ${ }^{\circledR}$ was $5600 \mathrm{mg} \mathrm{l}^{-1}$, which is defined as "practically non-toxic" in the EPA's toxicological terminology. However, the $48-\mathrm{h} \mathrm{EC}_{50}$ values of the 2 surfactants were classified as "moderately toxic" to midge larvae. Similarly, Henry et al. (1994) found that Rodeo (R) was "practically non-toxic" to several species of aquatic invertebrates in laboratory and field studies. In laboratory studies, Henry et al. (1994) found that Daphnia magna Straus was the most susceptible of the studied invertebrate species; the $\mathrm{LC}_{50}$ (median lethal concentration) for $D$. magna Straus to glyphosate was $117 \mathrm{mg} \mathrm{l}^{-1}$ and glyphosate tankmixed with Ortho X-77 Spreader ${ }^{\circledR}$ and Chem-Trol ${ }^{\circledR}$ drift retardant (Chemorse, LTD., Des Moines, Iowa) was $70 \mathrm{mg} \mathrm{l}^{-1}$. These values are rated as practically non-toxic" and "slightly toxic." of the 2 components mixed with the Rodeo ${ }^{\circledR}$ formulation, Henry et al. (1994) found that Ortho X-77 Spreader $^{\circledR}$ in laboratory tests was about 83-136 times more toxic than glyphosate with a $\mathrm{LC}_{50}$ of $2.0 \mathrm{mg} \mathrm{l}^{-1}$ ("moderately toxic"), whereas Chem-Trol ${ }^{\circledR}$ drift retardant was rated as "practically nontoxic."

Henry et al. (1994) and Linz et al. (1999) conducted field experiments in North Dakota on effects of glyphosate on wetland invertebrates and water quality. In 1990, Henry et al. (1994) used a predicted USDA-WS operational spray formulation (tank mixture of $2.5 \mathrm{~kg} \mathrm{ha}^{-1}$ glyphosate, $0.5 \% \mathrm{v} / \mathrm{v}$ Ortho X-77 Spreader $^{\circledR}$, Chem$\mathrm{Trol}^{\circledR}$ and water). The authors observed no difference in survival of caged invertebrates between treated and reference wetlands after 21 days post-treatment and concluded that operational use of glyphosate would not pose a hazard to aquatic invertebrates. Indeed, the projected wetland concentration of the most toxic of the spray formulation's components (Ortho X-77 Spreader ${ }^{\circledR}$ ) was 65 times less than the laboratory $\mathrm{LC}_{50}$ of $2.0 \mathrm{mg} \mathrm{l}^{-1}$ (Henry et al., 1994).

Linz et al. (1999) found that numbers of Gastropoda (4X greater), Corixidae (5X) and Chironomidae (7X) were all significantly greater in treated wetlands than reference, whereas numbers of Chaoboridae were $3 \times$ greater in reference wetlands than treated wetlands. Glyphosate treatments did not reduce or increase numbers of Copepoda, Ostracoda, Cladocera, Crustacea, Hydracarina and Oligochaeta.

The USEPA has classified glyphosate formulations as "slightly toxic" to "moderately toxic" to amphibians and "slightly toxic" to "practically non-toxic" to fish (Giesy et al., 2000). Cattail-dominated wetlands are generally marginal habitat for fishes because of high salinity levels and shallow-water depths, the latter making wetlands prone to summer- and winter-kill. Glyphosate does not bioaccumulate in amphibians and fishes, but applications to aquatic vegetation in water bodies having already low levels of dissolved oxygen or high temperatures could become hazardous to these groups because of increased eutrophication caused by mass decay of vegetation (Folmar et al., 1979).

\subsection{Glyphosate treatment effects on birds using cattail-dominated wetlands}

In 1985 and 1986, Solberg and Higgins (1993) found that glyphosate-treated wetlands had greater pair densities of waterfowl (Anatidae) than did reference wetlands. Densities of waterfowl nests, however, were similar between treatment and reference wetlands. In a pilot study, Linz et al. (1992) conducted pre-treatment and post-treatment counts during late summer in 4 treated wetlands in North Dakota and showed that numbers of marsh wrens (Cistothorus palustris Wilson) and 2 species of rails [sora (Porzana carolina L.) and Virginia rail (Rallus limicola Vieillot)] declined significantly. Numbers of adult ducks, ducklings and shorebirds (Scolopacidae) increased in the post-treatment period by multiples that ranged from 2 to $3 \times$ their pre-treatment numbers; the increases were not statistically significant due to small sample size and large variability in counts among wetlands (Linz et al., 1992).

From 1990 to 1993, Linz et al. (1996a,b, 1997) investigated impacts of glyphosate-treated wetlands on spring use by numerous wetland-dependent bird species in North Dakota. The authors found that marsh wren, red-winged blackbird and yellow-headed blackbird numbers declined significantly in at least 1 of the study years following application (Linz et al., 1996a). On the other hand, numbers of waterfowl responded positively and significantly to glyphosate treatments in post-treatment years (Linz et al., 1996b). Numbers of diving ducks (Aythyinae) increased each year during 2 years of post-treatment counts, whereas dabbling ducks (Anatinae) increased significantly only in the second year post-treatment. Two members of the Rallidae family [sora and American coot (Fulica americana Gmelin)] showed contrasting responses to glyphosate treatments. Numbers of American coots increased in treated wetlands during each of 2 post-treatment years, whereas sora numbers declined in the first year post-treatment but not in the second (Linz et al., 1997). However, even in the second year posttreatment, sora numbers remained much higher in reference wetlands $(>2 \times)$ than treated wetlands. Linz and Blixt (1997) demonstrated that numbers of black terns (Chlidonias niger L.), a species that was in decline in some areas of its range, were positively correlated with wetland proportions of open water and dead cattail resulting from applications of glyphosate.

Although most of the research conducted on effects of cattail reduction from glyphosate was on bird species using wetlands in spring and summer, a winter study was conducted on ringednecked pheasants (Phasianus colchicus L.), which use residual cattail cover winter cover (Homan et al., 2000, 2003). The research compared spring territorial crowing calls between treated and reference $23-\mathrm{km}^{2}$ quadrats. The data suggested that the proximity of glyphosate-treated wetlands did not affect male pheasants' choice of upland territories. No difference was detected in numbers of territorial crowing calls in the quadrats where all cattail- 
dominated wetlands $>2$ ha had been treated with glyphosate compared to similar quadrats with untreated wetlands.

\section{Discussion}

\subsection{Ecological effects}

Aquatic invertebrates makeup 70-99\% by volume of waterfowl diets during the reproductive season (Swanson and Duebbert, 1989) and correlations between densities of aquatic invertebrates and waterfowl numbers have been detected (Murkin et al., 1982). Moreover, a decrease in aquatic invertebrate density can slow the rate of duckling growth and ultimately reduce survival rate (Cox et al., 1998; Hunter et al., 1984). Thus, an economically important natural resource is potentially at risk when pesticides are applied to wetlands. With this in mind, it was not surprising that scientists focused on responses of invertebrates to glyphosate treatments.

Henry et al. (1994) found the $\mathrm{LC}_{50}$-value of glyphosate tank mix for the most sensitive of the tested invertebrate species was $117 \times$ greater than the highest in vivo concentration found in glyphosatetreated wetlands. Thus, direct negative effects from glyphosate toxicity were not expected nor detected. Indirect effects, especially from declines in the levels of dissolved $\mathrm{O}_{2}$ (DO), presented a more serious hazard to invertebrate survival. For example, glyphosate treatments on dense cattail stands will generate nearly 4 tonne $\mathrm{ha}^{-1}$ of decaying vegetation, which could dramatically reduce DO levels (Neely and Baker, 1989). However, Linz et al. (1999) showed that DO levels were similar between glyphosatetreated and reference wetlands. This observation agrees with Cole's (1985) assessment that wind-driven waves and spray in open areas of wetlands increase the absorptive surface at the air-water interface, moving DO down the water column and offsetting any reduction in DO from decomposition. The plentiful supply of nutrients from mass decomposition of decaying emergent vegetation likely increased algal production from more sunlight on the water surface and adequate levels of DO probably contributed to increased numbers of both grazing and predacious invertebrates and a commensurate increase in waterfowl use. Murkin and Kadlec (1986) and Solberg and Higgins (1993) obtained similar results from glyphosate-induced cattail reduction showing increased use by waterfowl and increased abundance of invertebrate species important to waterfowl (e.g., C. riparius). We speculate that black terns, another species dependant on wetlands for reproduction, responded positively to glyphosate treatments not only because of availability of nesting substrate provided by mats of dead cattail stems, but from an increase in food resources provided by flying invertebrates hatching from the opened wetlands (Linz and Blixt, 1997; Linz et al., 1994).

Of course, the fragmentation of dense stands of cattails will cause reductions in use of treated wetlands by some vertebrate species. Reduction of cattail coverage has a negative effect on blackbirds and wrens because they require vertical nest substrate to attach nests (Linz et al., 1996a). Abundance of rails (Rallidae) and bitterns (Ardeidae) and some species of ducks that build overwater nests within living stands of emergents will decline in treated wetlands (Krapu et al., 1979; Linz et al., 1997). Additionally, pheasants, deer and other furbearers that use standing residual cattail for winter cover can be affected; and lastly, cattail reduction affects muskrats, which eat the rhizomes of cattail and build lodges from cattail stems that, in turn, may be used as nest sites by birds. The negative impacts of glyphosate treatment on these species are ameliorated by staggering glyphosate treatments on large wetland complexes, which helps diversify the stages of cattail regeneration and provide heterogeneous nesting and foraging habitat for negatively impacted species. Moreover, USDA-WS annually sprays only about $1 \%$ of the total cattail available in North Dakota (USDA, 2006). Cattail recovery is dependent on water levels but our post-treatment observations suggested that most wetlands develop a good interspersion of cattail and open water in 4-6 years. Finally, we believe that the scale of natural processes that affect the demise and regrowth of cattail stands in the PPR landscape dwarfs that of the USDA-WS cattail management program. The inherent dynamics causing natural creation and destruction of cattail are an ongoing phenomenon in the PPR and wetland-dependent species deprived of cattail cover in one wetland will likely move to a nearby wetland that meets their ecological needs (Homan et al., 2003).

\subsection{Impact on USDA-WS cattail management program}

In 2000, the USDA-WS updated their cattail management protocol after 20 years of cumulative research on glyphosate efficacy and application methodology. The changes included lowering the spray volume from $47 \mathrm{lha}^{-1}$ to $281 \mathrm{ha}^{-1}$ and application rate from a minimum label-recommended rate of $2.5 \mathrm{~kg} \mathrm{ha}^{-1}$ to a below-label rate of $2.2 \mathrm{~kg} \mathrm{ha}^{-1}$. Although applications as low as $1.7 \mathrm{~kg} \mathrm{ha}^{-1}$ provide moderate control of cattail (Messersmith et al., 1992), the treatment longevity range of $4-6$ years, sought by USDAWS, might not be achieved (Linz et al., 1992).

The research that supported use of a lower spray volume $\left(28 \mathrm{lha}^{-1}\right)$ was particularly important to the cattail management program, because it allowed rotary-winged aircraft (helicopters) to compete with fixed-wing aircraft in cost effectiveness. The deployment of helicopters in 2000 caused a chain of protocol alterations that led to a reduction in the minimum basin-size requirement (from 6 ha to 4 ha) and elimination of drift retardant. The precision of spray coverage achieved by helicopter led to lower risks of harm to adjacent, glyphosate-sensitive crops, which had been a cause of litigation concerns by fixed-wing applicators.

\subsection{Economic analysis of cattail management program}

In 2009, treatment cost, including glyphosate, surfactant and helicopter application, was about US\$95/ha, a decrease of about 30\% since 1995 (Leitch et al., 1997; Linz et al., 1995). Assuming daily sunflower consumption by one blackbird is $0.009 \mathrm{~kg} \mathrm{day}^{-1}$ (Peer et al., 2003), each bird will damage $0.27 \mathrm{~kg}$ over a 30-day damage period. With sunflower's 5-year (2004-2009) market price valued at US $\$ 0.37 \mathrm{~kg}^{-1}$ (NASS, 2010b), a single blackbird (combining sexes and species) damages about US\$0.10 of sunflower year ${ }^{-1}$. Thus, growers must anticipate an average of 950 blackbirds ha ${ }^{-1}$ (US $\$ 95 \mathrm{ha}^{-1} / \mathrm{US} \$ 0.10 \mathrm{year}^{-1}$ ) of cattail to justify treatment costs. Regrowth of cattail following treatment is contingent on water levels. If water depths remain stable at $>30 \mathrm{~cm}$, there should be few living cattail for at least 4 years and perhaps up to 6 years (Merendino and Smith, 1991). A treatment that is effective for at least 4 years requires only 238 blackbirds day ${ }^{-1} \mathrm{ha}^{-1}$ of cattail to justify costs, provided sunflower is planted every year on lands somewhere near the treated wetland. Cattail-dominated wetlands harboring $>238$ blackbirds ha ${ }^{-1}$ are common in North Dakota and roosts containing $>1000$ blackbirds ha ${ }^{-1}$ are located each year in sunflower growing areas of the PPR (Linz et al., 1992, 2003).

\section{Conclusions and recommendations}

Presumably, dispersing dense concentrations of blackbirds from their roost sites spreads bird damage over a larger area. This management tactic appears to have helped sunflower producers reduce the severity of damage sustained in fields located near cattail-dominated wetlands. Although statistical evidence to support this concept is indirect (Linz et al., 1995), the continued 
strong demand for the program suggests empirically that the program is achieving its objective.

Wildlife groups often disagree on the methods used by agriculture to solve wildlife conflicts. The USDA-WS cattail management program, however, appears to meet the requirements of wildlife interests and agriculture (McEnroe, 1992; Stromstad, 1992). Fragmenting dense cattail stands returns wetlands to their original configuration, which promotes avian diversity while preventing the formation of large roosting aggregations of blackbirds. We submit that the current cattail management program has been well documented and has the potential to be the basis for further cooperation between wildlife and agricultural groups.

\section{Acknowledgements}

We thank T. Pugh and R. Wimberly for providing up-to-date information on the USDA-WS cattail management program. M. Klosterman, P. Mastrangelo, L. Penry, T. Pugh and M. Strassburg provided helpful comments on an earlier draft of the manuscript. Mention of commercial products does not imply endorsement by the U.S. Department of Agriculture.

\section{References}

Alibhai, M., Stallings, W.C., 2001. Closing down on glyphosate inhibition - with a new structure for drug discovery. Proc. Natl. Acad. Sci. 98, 2944-2946.

Bangsund, D.A., Leistritz, F.L., 1995. Economic Contribution of the United States Sunflower Industry. Agricultural Economics Report No. 327-S. North Dakota State University, Fargo, North Dakota, USA.

Besser, J.F., Berg, W.J., Knittle, C.E., 1981. Late-summer feeding patterns of redwinged blackbirds in a sunflower-growing area of North Dakota. Bird Contro Seminar Proc. 8, 209-214.

Beule, J.D., 1979. Control and management of cattails in southeastern Wisconsin wetlands. Wisconsin Dept. Nat. Resour. Tech. Bull. 112.

Bronstad, H.O., Friestad, J.D., 1985. Behavior of glyphosate in the aquatic environment. In: Grossbard, E., Atkinson, D. (Eds.), The Herbicide Glyphosate. Butterworth, London, pp. 200-205.

Buhl, K.J., Faerber, N.L., 1989. Acute toxicity of selected herbicides and surfactants to larvae of the midge Chironomus riparius. Arch. Environ. Contam. Toxicol. 18, $530-536$.

Cole, D.J., 1985. Mode of action of glyphosate - a literature analysis. In: Grossbard, E., Atkinson, D. (Eds.), The Herbicide Glyphosate. Butterworth, London, pp. 48-74.

Comes, R.D., Kelley, A.D., 1989. Control of common cattail with postemergence herbicides. J. Aquat. Plant Manage. 27, 20-23.

Cox Jr., R.R., Hanson, M.A., Roy, C.C., Euliss Jr., N.H., Johnson, D.H., Butler, M.G., 1998 Mallard duckling growth and survival in relation to aquatic invertebrates. J. Wildl. Manage. 62, 124-133.

Davis, C.B., van der Valk, A.G., 1978. The decomposition of standing and fallen litter of Typha glauca and Scirpus fluviatilis. Can. J. Bot. 56, 662-675.

Farrer, E.C., Goldberg, D.E., 2009. Litter drives ecosystem and plant community changes in cattail invasion. Ecol. Appl. 19, 398-412.

Folmar, L.C., Sanders, H.L., Julin, A.M., 1979. Toxicity of the herbicide glyphosate and several of its formulations to fish and aquatic invertebrates. Arch. Environ Contam. Toxicol. 8, 269-278.

Forcey, G.M., Linz, G.M., Thogmartin, W.E., Bleier, W.J., 2008. Modeling wetland blackbird populations as a function of waterfowl abundance in the Prairie Pothole Region of the United States and Canada. Environ. Bioindicators 3, 124-135.

Franz, J.E., Mao, M.K., Sikorski, J.A., 1997. Glyphosate: A Unique Global Herbicide. Am. Chem. Soc., Washington, D.C., USA.

Galatowitsch, S.M., van der Valk, A.G., 1994. Restoring Prairie Wetlands: An Ecological Approach. Iowa State University Press, Ames, Iowa, USA.

Giesy, J.P., Dobson, S., Solomon, K.R., 2000. Ecotoxicological risk assessment for Roundup ${ }^{\circledR}$ herbicide. Rev. Contam. Toxicol. 167, 35-120.

Guarino, J.L., Cummings, J.L., 1985. Management implications derived from bird damage assessments in North Dakota sunflower. Eastern Wildl. Damage Control Conf. 2, 172-177.

Henry, C.J., Higgins, K.F., Buhl, K.J., 1994. Acute toxicity and hazard assessment of Rodeo $^{\circledR}$, X-77 Spreader $^{\circledR}$, and Chem-Trol ${ }^{\circledR}$ to aquatic invertebrates. Arch. Environ. Contam. Toxicol. 27, 392-399.

Homan, H.J., Bleier, W.J., Bergman, D.L., Linz, G.M., 1992. Using GIS to analyze wetland basins in northcentral North Dakota. In: Linz, G.M. (Ed.), Proceedings of a Cattail Management Symposium. Denver Wildlife Research Center and U.S. Fish and Wildlife Service, Fargo, North Dakota, USA, pp. 32-34.
Homan, H.J., Linz, G.M., Bleier, W.J., Carlson, R.B., 1994. Dietary comparisons of adult male common grackles, red-winged blackbirds and yellow-headed blackbirds in north central North Dakota. Prairie Nat. 26, 273-281.

Homan, H.J., Linz, G.M., Bleier, W.J., 2000. Winter habitat use and survival of female ring-necked pheasants (Phasianus colchicus) in southeastern North Dakota. Am. Midl. Nat. 143, 463-480.

Homan, H.J., Linz, G.M., Carlson, R.C., Bleier, W.J., 2003. Spring distribution of ringnecked pheasants (Phasianus colchicus) following cattail reduction with glyphosate herbicide. Wildl. Res. 30, 159-166.

Hotchkiss, N., Dozier, H.L., 1949. Taxonomy and distribution of North American cattails. Am. Midl. Nat. 41, 237-254.

Hothem, R.L., DeHaven, R.W., Fairaizl, S.D., 1988. Bird damage to sunflower in North Dakota, South Dakota and Minnesota, 1979-1981. U.S. Fish Wildl. Serv. Tech. Rep. 15.

Howe, C.M., Berrill, M., Pauli, B.D., Helbring, C.C., Werry, K., Veldhoen, N., 2004. Toxicity of glyphosate-based pesticides to four North American frog species. Environ. Toxicol. Chem. 23, 1928-1938.

Hunter, M.L., Witham, J.W., Dow, H., 1984. Effects of carbaryl-induced depression in invertebrate abundance on the growth and behavior of American black duck and mallard ducklings. Can. J. Zool. 62, 452-456.

Kantrud, H.A., 1986. Effects of Vegetation Manipulation on Breeding Waterfowl in Prairie Wetlands - a Literature Review. U.S. Fish and Wildlife Service, Washington, DC. Wildl. Serv. Tech. Rep. 3.

Kantrud, H.A., 1992. History of cattails on the prairies: wildlife impacts. In: Linz, G.M. (Ed.), Proceedings of a Cattail Management Symposium. U.S. Department of Agriculture, Denver Wildlife Research Center and U.S. Fish and Wildlife Service, Fargo, North Dakota, USA, pp. 9-12.

Kleingartner, L., 2002. Sunflower losses to blackbirds: an economic burden. In: Linz, G.M. (Ed.), Management of North American Blackbirds. Proceedings of a Special Symposium of The Wildlife Society 9th Annual Conference, 24-28 September 2002, Bismarck, North Dakota, USA, pp. 13-14.

Krapu, G.L., Talent, L.G., Dwyer, T.J., 1979. Marsh nesting by mallards. Wild. Soc. Bull. 7, 104-110.

Leitch, J.A., Linz, G.M., Baltezore, J.F., 1997. Economics of cattail (Typha spp.) control to reduce blackbird damage to sunflower. Agr. Ecosyst. Environ. 65, $141-149$.

Lembi, C.A., 1978. Results of 1978 aquatic herbicide trials in Indiana. North Cent. Weed Control Conf. 33, 102-103.

Linz, G.M., Blixt, D.C., 1997. Black terns benefit from cattail management in the northern Great Plains. Colonial Waterbirds 20, 617-621.

Linz, G.M., Homan, H.J., 1998. Tracing the history of blackbird research through an industry's looking glass. The Sunflower Magazine 18, 35-42.

Linz, G.M., Bolin, S.B., Cassel, J.F., 1983a. Postnuptial and postjuvenal molts of redwinged blackbirds in Cass County, North Dakota. Auk 100, 206-209.

Linz, G.M., Vakoch, D.L., Cassel, J.F., Carlson, R.B., 1983b. Food of red-winged blackbirds collected at a roost in late summer in Cass County, North Dakota. Prairie Nat. 15, 75-78

Linz, G.M., Vakoch, D.L., Cassel, J.F., Carlson, R.B., 1984. Food of red-winged blackbirds, Agelaius phoeniceus, in sunflower fields and corn fields. Canadian FieldNat. 98, 38-44.

Linz, G.M., Bergman, D.L., Bleier, W.J., 1992. Progress on managing cattail marshes with Rodeo ${ }^{\circledR}$ herbicide to disperse roosting blackbirds, Vertebr. Pest Conf. vol. 15, pp. 56-61.

Linz, G.M., Bergman, D.L., Blixt, D.C., Bleier, W.J., 1994. Response of black terns (Chlidonias niger) to glyphosate-induced habitat alterations on wetlands. Colonial Waterbirds $17,160-167$.

Linz, G.M., Bergman, D.L., Homan, H.J., Bleier, W.J., 1995. Effects of herbicide-induced habitat alterations on blackbird damage to sunflower. Crop Prot. 14, 625-629.

Linz, G.M., Blixt, D.C., Bergman, D.L., Bleier, W.J., 1996a. Response of red-winged blackbirds, yellow-headed blackbirds and marsh wrens to glyphosate-induced alterations in cattail density. J. Field Ornithol. 67, 167-176.

Linz, G.M., Blixt, D.C., Bergman, D.L., Bleier, W.J., 1996b. Response of ducks to glyphosate-induced habitat alterations in wetlands. Wetlands $16,38-44$.

Linz, G.M., Bergman, D.L., Blixt, D.C., McMurl, C., 1997. Response of American coots and soras to herbicide-induced vegetation changes in wetlands. J. Field Ornithol. 68, 450-457.

Linz, G.M., Bleier, W.J., Overland, J.D., Homan, H.J., 1999. Response of invertebrates to glyphosate-induced habitat alterations in wetlands. Wetlands 19, 220-227.

Linz, G.M., Peer, B.D., Homan, H.J., Wimberly, R.L., Bergman, D.L., Bleier, W.J., 2002. Has an integrated pest management approach reduced blackbird damage to sunflower? In: Clark, L., Hone, J., Shivik, J.S., Watkins, R.W., VerCauteren, K.C., Yoder, J.K. (Eds.), Human Conflicts With Wildlife: Economic Considerations. Proceedings of the 3rd NWRC Special Symposium of the National Wildlife Research Center, 1-3 August 2000, Fort Collins, Colorado, USA, pp. 132-137.

Linz, G.M., Sawin, R.A., Lutman, M.W., Homan, H.J., Penry, L.B., Bleier, W.J., 2003. Characteristics of spring and fall blackbird roosts in the northern Great Plains. Wildlife Damage Manage. Conf., vol. 10, pp. 220-228.

Linz, G.M., Homan, H.J., Wimberly, R.L., Mastrangelo, P., Bleier, W.J., 2004. Management of cattail (Typha spp) stands with glyphosate to disperse blackbirds. Int. Sunflower Conf. 16, 411-416.

Mann, R.M., Bidwell, J.R., 1999. The toxicity of glyphosate and several glyphosate formulations to four species of southwestern Australian frogs. Arch. Environ. Contamin. Toxicol. 36, 193-199.

McEnroe, M., 1992. Cattail management: views of the U.S. Fish and Wildlife Service. In: Linz, G.M. (Ed.), Proceedings of a Cattail Management Symposium. U.S. 
Department of Agriculture, Denver Wildlife Research Center and U.S. Fish and Wildlife Service, Fargo, North Dakota, USA, pp. 42-44.

Merendino, M.T., Smith, L.M., 1991. Influence of drawdown date and reflood depth on wetland vegetation establishment. Wildl. Soc. Bull. 19, 143-150.

Messersmith, C.G., Christianson, K.M., Thorsness, K.B., 1992. Influence of glyphosate rate, application date and spray volume on cattail control. North Dakota Farm Res. 49, 27-28.

Monsanto Company, 1988. Rodeo ${ }^{\circledR}$ Herbicide for Aquatic Vegetation Management. Monsanto Agric. Co. Tech. Man., St. Louis, Missouri, USA.

Mueller, M.R., Lembi, C.A., 1975. Herbicide treatments for cattails, spatterdock and reed canarygrass. Proc. North Cent. Weed Control Conf. 30, 169.

Murkin, H.R., Kadlec, J.A., 1986. Relationships between waterfowl and macroinvertebrate densities in a northern prairie marsh. J. Wildl. Manage. 50, 212-217.

Murkin, H.R., Kaminski, R.M., Titman, R.D., 1982. Responses by dabbling ducks and aquatic invertebrates to an experimentally manipulated cattail marsh. Can. J. Zool. 60, 2324-2332.

National Agricultural Statistics Service (NASS), 2010a. January Annual Crop Production Report. http://www.sunflowernsa.com/stats/ (14 April 2010).

National Agricultural Statistics Service (NASS), 2010b. Agricultural Prices: 1964-2010. http://usda.mannlib.cornell.edu/MannUsda/viewDocumentInfo. do?documentID=1002/ (14 April 2010).

Neely, R.K., Baker, J.L., 1989. Nitrogen and phosphorus dynamics and the fate of agricultural runoff. In: van der Valk, A. (Ed.), Northern Prairie Wetlands. Iowa State University Press, Ames, Iowa, USA, pp. 92-132.

Otis, D.L., Kilburn, C.M., 1988. Influence of environmental factors on blackbird damage to sunflower. U.S. Fish Wildl. Serv. Tech. Rep. 16

Peer, B.D., Homan, H.J., Linz, G.M., Bleier, W.J., 2003. Impact of black-bird damage to sunflower: bioenergetic and economic models. Ecol. Appl. 13, $248-256$.

Pyke, G.H., 1984. Optimal foraging theory: a critical review. Ann. Rev. Ecol. Syst. 15 523-575.
Ralston, S.T., Linz, G.M., Bleier, W.J., Homan, H.J., 2007. Cattail distribution and abundance in North Dakota. J. Aquat. Plant Manage. 45, 21-24.

Relyea, R.A., 2005. The lethal impact of roundup on aquatic and terrestrial amphibians. Ecol. Appl. 15, 1118-1124.

Sojda, R.S., Solberg, K.L., 1993. Management and Control of Cattails. U.S. Fish and Wildlife Service, Fish and Wildlife Leaf. 13.4.13, Washington, D.C., USA

Solberg, K.L., Higgins, K.F., 1993. Effects of glyphosate herbicide on cattails, invertebrates and waterfowl in South Dakota wetlands. Wildl. Soc. Bull. 21 299-307.

Stevens, O.A., 1963. Handbook of North Dakota Plants. North Dakota Institute for Regional Studies, Fargo, North Dakota, USA

Stromstad, R., 1992. Cattail management: the North Dakota Game and Fish department perspective. In: Linz, G.M. (Ed.), Proceedings of a Cattail Management Symposium. U.S. Department of Agriculture, Denver Wildlife Research Center and U.S. Fish and Wildlife Service, Fargo, North Dakota, USA pp. 38-41.

Stuckey, R.L., Salamon, D.P., 1987. Typha angustifolia in North America: a foreigner masquerading as a native. Am. J. Bot. 74, 757 .

Swanson, G.A., Duebbert, H.F., 1989. Wetland habitats of waterfowl in the Prairie Pothole Region. In: van der Valk, A.G. (Ed.), Northern Prairie Wetlands. Iowa State University Press, Ames, Iowa, USA, pp. 228-267.

USDA (United States Department of Agriculture), 2006. Management of Blackbird Species to Reduce Damage to Sunflower, Corn and Other Small Grain Crops in Prairie Pothole Region of North Dakota and South Dakota. Monitoring Report and Amendment to the Environmental Assessment. Bismarck, North Dakota, USA. 36.

van der Valk, A.G., Davis, C.B., 1978. The role of seed banks in the vegetation dynamics of prairie glacial marshes. Ecology 59, 322-335.

Waters, I., Shay, J.M., 1992. Effect of water depth on population parameters of a Typha glauca stand. Can. J. Bot. 70, 349-351.

Weller, M.W., 1975. Studies of cattail in relation to management for marsh wildlife. Iowa State J. Res. 49, 383-412. 